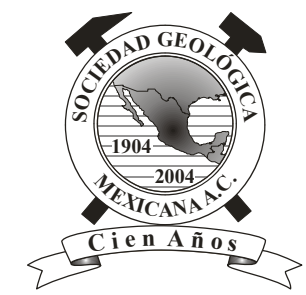

\title{
Isolated mantis shrimp dactyli from the Pliocene of North Carolina and their bearing on the history of Stomatopoda
}

\author{
Carolin Haug ${ }^{1, *}$, Kevin R. Shannon ${ }^{2}$, Torrey Nyborg ${ }^{3}$, Francisco J. Vega ${ }^{4}$ \\ ${ }^{1}$ Department of Cytology and Evolutionary Biology, Zoological Institute and Museum, University of Greifswald, Soldmannstrasse 23, \\ 17487 Greifswald, Germany. \\ 24137 Sunset Drive, Martinsville VA, 24112, USA. \\ ${ }^{3}$ Department of Earth and Biological Sciences, Loma Linda University, Loma Linda CA, 92350, USA. \\ ${ }^{4}$ Instituto de Geología, UNAM, Ciudad Universitaria, México DF, 04510, Mexico. \\ *carolin.haug@palaeo-evo-devo.info
}

\begin{abstract}
We describe 54 fragmentary specimens from the Pliocene of North Carolina that represent isolated dactyli of mantis shrimps. These specimens are preserved uncompressed within three dimensions in calcium phosphate. The dactyli have an estimated maximum length of 15 millimeters and bear six spines. The specimens appear to be hollow and preserve fine details, especially a narrow crest on the dorsal side of the spines, a functional blade edge that has not been previously found on any fossil stomatopod. The specimens are provisionally attributed to the species Squilla empusa, found nowadays along the entire East coast of the United States of America. Fossil occurrences are known from the Pleistocene of Maryland and from the late Pleistocene or early Holocene of Connecticut. Though isolated dactyli are less informative on the taxonomic level, they can be important on the paleo-ecological level, positively demonstrating the presence of ambush predators in an investigated paleo-community. Given the scarce stomatopod fossil record and the exceptional three-dimensional preservation, the finding of these specimens, despite their fragmentary nature, is regarded as significant.
\end{abstract}

Keywords: Squilla empusa, three-dimensional preservation, imaging, phosphatized fossils, paleoecology, predators.

\section{Resumen}

Se describen 54 especimenes fragmentarios del Plioceno de Carolina del Norte, los cuales representan dactilos aislados de mantis marinas. Estos ejemplares se preservaron tridimensionalmenteen fosfato de calcio, sin compresión alguna. Los dactilos tienen una longitud máxima estimada de 15 milímetros y tienen seis espinas. Los especímenes parecen estar huecos y preservan detalles finos, especialmente una cresta estrecha en el lado dorsal de las espinas, que es una hoja afilada funcional no reportada previamente para ningún estomatópodo fósil. Los especímenes son provisionalmente asignados a la especie Squilla empusa, la cual se encuentra actualmente a lo largo de la costa Este de los Estados Unidos de América. Se conocen registros fósiles de esta especie del Pleistoceno de Maryland y del Pleistoceno u Holoceno temprano de Connecticut. Aunque los dáctilos aislados son poco significativos a nivel taxonómico, pueden ser importantes a nivel paleoecológico, puesto que demuestran la presencia de depredadores en una paleocomunidad en estudio. Dado el escaso registro fósil de estomatópodos y la excepcional preservación tridimensional, el hallazgo de estos especímenes, a pesar de su naturaleza fragmentaria, se considera significativo.

Palabras Clave: Squilla empusa, preservación tridimensional, manipulación de imágenes, fósiles fosfatizados, paleoecología, depredadores. 


\section{Introduction}

Mantis shrimps, Stomatopoda (Latreille, 1816), are impressive representatives of the "higher crustaceans", Malacostraca (Latreille, 1802). Extant mantis shrimps are characterized by several morphological peculiarities that differentiate them from other malacostracans. Among these features are the highly specialized eyes (Kleinlogel and Marshall, 2006; Chiou et al., 2008) and, of course, the ferocious raptorial appendages (e.g., Patek et al., 2004). Other unique features are the possession of feathery gills on the pleopods (Boxshall and Jaume, 2009; Maas et al., 2009) and the structure of the tail fan (e.g., Schram, 1986).

While modern mantis shrimps are so different from other crustaceans, fossil representatives have provided insight into their evolutionary history, bridging these morphological differences (e.g., Schram, 2007; Haug J.T. et al., 2010). Fossil mantis shrimps are well known from the Carboniferous, Jurassic, Cretaceous, and Cenozoic (for a recent summary, see Schram, 2010). Most forms from pre-Cenozoic times represent offshoots of the evolutionary lineage towards the modern representatives of stomatopods, Verunipeltata Haug J.T., Haug, C., Maas, Kutschera, and Waloszek, 2010 (Haug J.T. et al., 2010). Very few representatives of Verunipeltata are present in the Cretaceous, yet all Cenozoic findings fall into this monophyletic group.

In general, the fossil record of stomatopods is considered to be scarce and fragmentary. Therefore, new findings provide additional information. We describe here isolated stomatopod dactyli from the Pliocene of North Carolina. We furthermore discuss how this finding will influence future search for fossil stomatopod material and which biological questions can be possibly addressed with the material presented here.

\section{Material and Methods}

\subsection{Site location}

The Upper Pliocene shell bed site that provided the background for this study is located at the Bladen County Landfill Annex site, Bladen County, south of Elizabethtown, North Carolina. The approximate coordinates for the site are $34^{\circ} 36^{\prime} 24.58^{\prime \prime} \mathrm{N}, 78^{\circ} 36^{\prime} 35.56^{\prime \prime} \mathrm{W}$ (Figure 1). The Pliocene layer at this locality overlies the Upper Cretaceous Bladen Formation (Campanian) pebble lag deposit (Figure 2 ). The Annex site has been claimed and is now closed until further notice.

\subsection{Age of the shell beds at Elizabethtown, North} Carolina

Carter et al. (1988) list three distinct Pliocene shell beds assigned to the Bear Bluff Formation overlying the

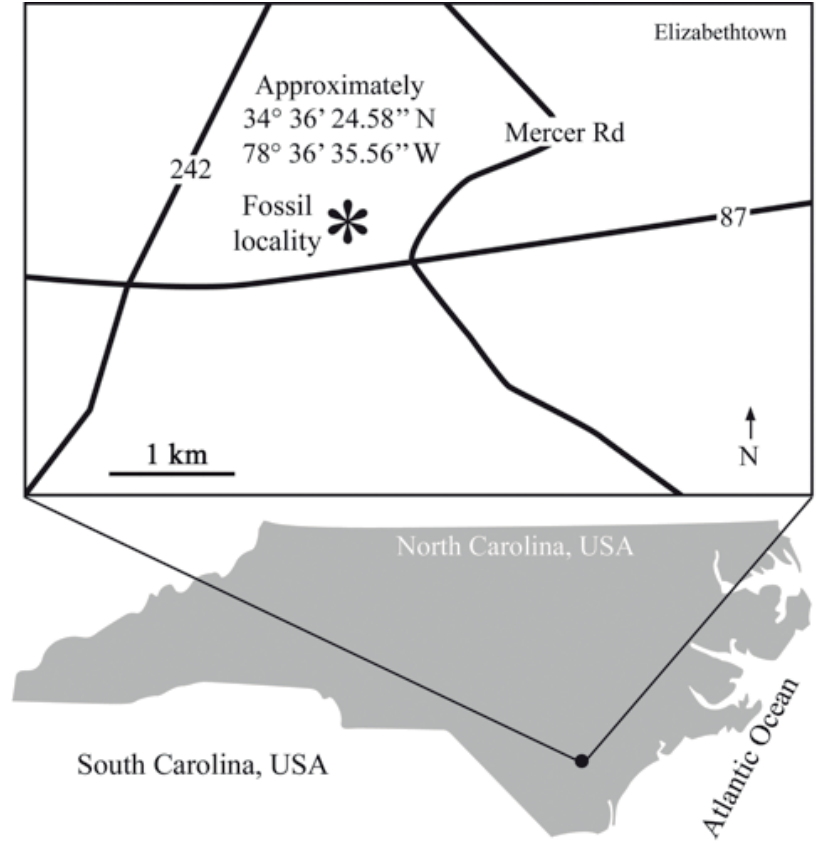

Figure 1. Generalized map of the fossil locality.

Campanian Black Creek (now Tar Heel) Formation at their Elizabethtown locality. Stratigraphic provenance of the stomatopod fossils is inferred to be from an aragonite leached section of Bed 1 of Carter et al. (1988) (lower unit in Figure 2). Ward and Gilinsky (1993) state that the wellpreserved mollusk beds at Elizabethtown are the lateral shoreward equivalent of the leached calcarenites at Bear Bluff on the Waccamaw River near Conway South Carolina. Campbell and Campbell (1995) synonymize the Bear Bluff with the Upper Goose Creek Limestone. In that same publication, they place the age of the Elizabethtown mollusk beds as older than the Lower Waccamaw, but younger than the Duplin or between 2.7 and 2.9 Ma approximately. They also note the similarity of the fauna to the stratotype Chowan River Formation.

\subsection{Collections and processing}

Bulk sediment samples were collected from the Upper Pliocene Bear Bluff Formation (equivalent to Chowan River Formation) shell hash layer at the Elizabethtown Annex dumpsite. The majority of the samples were collected during the period of 1996-2001. The first stomatopod element, a raptorial dactylus, was recovered in 1996 with additional specimens recovered afterwards.

The sediments were first dried and gently fractionated through nested sieves of \# 4 mesh $(4.75 \mathrm{~mm})$ down to \# 35 mesh $(0.500 \mathrm{~mm})$ to remove smaller clay and sand particulates. The fractions were rinsed with copious amounts of water until the supernatant ran clear and the fractions were then dried. Further fractioning was not performed in order to reduce any undue breakage of the more delicate 


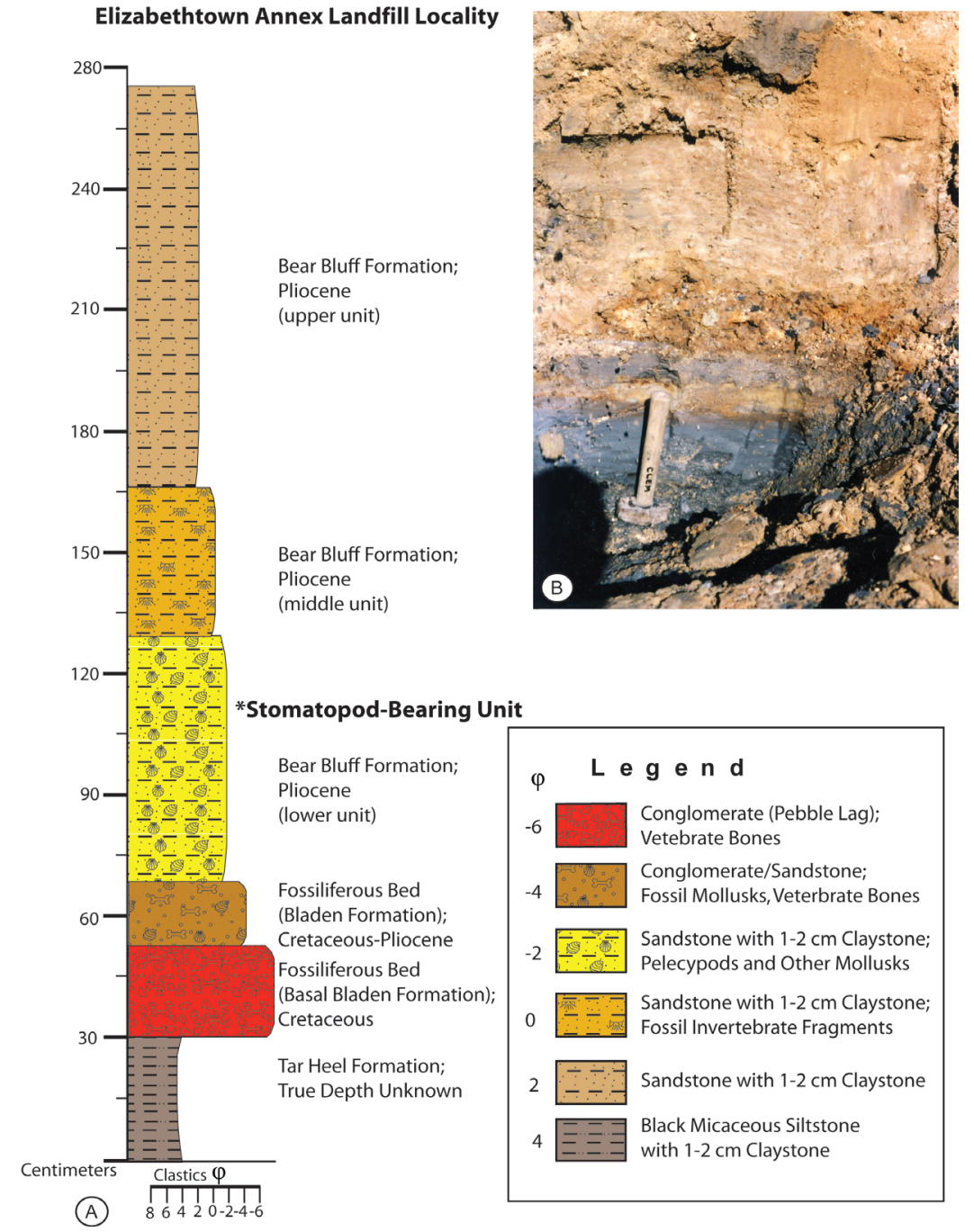

Figure 2. The Elizabethtown (Bladen County) Annex Landfill Site Locality. A) Geologic profile. B) Excavation site.

fossils present.

Larger sediment fractions were scanned and specimens picked macroscopically. Sediment fractions of \# 5 mesh $(4.0 \mathrm{~mm})$ and lower were scanned and picked with the aid of an American Optical Series Forty binocular microscope.

The stomatopod raptorial claws and fragments were found throughout all the Pliocene shell hash fractions. Since there is a definite bioturbated contact layer between the Pliocene shell hash bed and the underlying Cretaceous basal Bladen Formation (pebble lag) (Figure 2A), some of the claw fragments have the rust-colored, fine sand of the underlying Cretaceous layer embedded in the cavities of the dactyli fragments. Other dactyli fragments possess fine carbonate film and fine quartz sand matrix in some cavities as a result of deposition in the upper sections of the shell hash layer. Eventhough the fractioning process may have caused breakage of the stomatopod elements, there was no real evidence of fresh breakage during the scanning process.

Notation of the more numerous smaller mollusks found during the above mentioned fractionation process can serve as a horizon marker. The more prominent gastropods found were a large number of Prunum limatulum (Conrad, 1834) and Turbonilla sp. (Risso, 1826). Bivalves include Crassatella sp. (Lamarck, 1799) and abundant fragments of Raeta sp. cf. undulata (Gould, 1851) throughout the entire shell hash layer (see Ward and Gilinsky, 1993).

Some of the more outstanding Pliocene fish elements found in the shell hash layer include a high number of well-preserved otoliths along with well-preserved tiny teeth. These otoliths exhibit characteristics associated with Scianenidae (e.g., Sciaenops sp. Gill, 1863, Cynoscion sp. Gill, 1861, Equetus sp. Rafinesque, 1815, and/ or Micropogonias sp. Bonaparte, 1831; see Fitch and Lavenberg, 1983).

\subsection{Documentation}

All specimens were documented on a Leica DM 2500 $\mathrm{P}$ compound microscope, with a $2.5 \mathrm{x}$ pol objective and a Scopetek DCM 510 ocular camera, resulting in an effective 
magnification of 25 times. Due to the limited depth of field, image stacks (50 micron $\mathrm{z}$-distance) were recorded and later fused with the freely available program CombineZP. Due to the limited field of view and the larger size of some of the specimens, these were recorded with several stacks. The fused images were then stitched with the photomerge function of Adobe Photoshop CS3. The resulting image is a composite image sensu Haug C. et al. (2009a).

As the surface of the specimens is highly reflective, all images were recorded under crossed polarized light (Schaarschmidt, 1973; Bengtson S., 2000; Haug C. et al., 2011; Haug J.T. et al., 2011; Kerp and Bomfleur, 2011). The light was provided by four independent fiber light sources in an evenly arranged pattern.

Some specimens have a very wide range of brightness, from very dark brown to bright white areas. Although polarized light partly equalizes such differences, the brightness range of the camera could not document these specimens satisfactorily with a single exposure setting. Therefore, these specimens were documented in two steps. First, they were documented with a "normal" exposure time, which left the darker areas almost invisible, but provided structural details for the bright areas. In a second step, the same image detail was overexposed, which left the bright areas without information, but provided the details of the dark areas. The overexposed image was placed as a separate layer on top of the normally exposed image in Adobe Photoshop CS3. The white (uninformative) areas of the top layer were marked with the magic wand tool; the selection was assigned a feather and cut out. In this way, the brighter areas with structural details of the underlying layer became visible. The final image combines surface information for both very bright and very dark areas, resulting in a fully informative image. This procedure roughly equals an HDR-treatment.

Large specimens were documented from three directions, from both lateral sides and from the adorned side (Figures 3A-D, 4A-H, 4J-N). Smaller specimens were documented from two directions (Figures 4I, 5). Specimens representing broken off spines or smaller pieces of the dactylus were documented from the two lateral views. Broken pieces of the main dactylus body were documented from the outer and inner side. For better comparison, all specimens were depicted in the same scale (Figures 3-5). Additionally, details of the "cutting" edges of the spines and preservational peculiarities were documented as detailed views (Figure 6).

One specimen was analyzed with X-ray-fluorescence with a Bruker Tracer $3 \mathrm{~V}+$, which measures the elemental composition of a specimen. The same specimen was documented under optical macro-fluorescence settings, with a cyan filter in front of the light sources and a red filter in front of the camera (Canon Rebel T3i; for details see Haug J.T. and Haug C., 2011; Haug J.T. et al., 2011). To restrict the information of the image to the light emitted due to autofluorescence of the specimen, the remaining green light that was not absorbed entirely by the filters was artificially removed by reducing the green saturation in Adobe Photoshop CS3 (Figure 3E).

The four largest and most complete specimens were additionally documented as stereo images (Haug C. et al., 2009a, 2011), also in three directions (Figure 7). As the natural color of the specimens interferes with the red channel, a disturbing flickering is perceived when observing red-cyan stereo images produced from the original color images, which dampens the depth effect of the images. Therefore, the images were reduced to gray scale before assembling the red-cyan stereo images.

\section{Results}

Fifty-four fragmentary specimens identified as parts of stomatopod dactyli have been investigated (Accession number NCSM 12837, specimens NCSM 11642 to $11675,11677$ to 11686 and 11689 to 11698$)$. Specimens are deposited at the North Carolina Museum of Natural Sciences, Raleigh, NC. Due to the presence of spines, specimens are identified as dactyli parts of the large pair of raptorial appendages, as the three succeeding pairs of smaller raptorial appendages lack such spines in any stomatopod species. Four of the 54 specimens are rather complete (Figure 3). The dactyli have an estimated maximum length of up to $15 \mathrm{~mm}$ and carry six spines. Two of these specimens represent the dactylus of the right appendage and two represent the left appendage.

Fourteen specimens are identified as a central part of a dactylus, ranging from larger pieces to smaller fragments, in which only two insertions of the spines are recognizable (Figure 4). Of these specimens, five can be identified as parts of dactyli of the right appendage, three as parts of dactyli of the left appendage; six cannot be attributed to the left or the right appendage.

Thirty-six more specimens that are fragmentary represent isolated spines or cuticle parts of the main part of the dactylus (Figure 5). Due to the fragmentary nature of these specimens, they cannot be attributed to a particular body side.

An observed surface detail that represents the original morphology is a narrow crest on the functionally dorsal side of the spines of the dactyli (Figure 6A, B). This structure can be found on all four well-preserved specimens, but also on some of the isolated spines (e.g., Figure 5B, D), which supports the hypothesis of the isolated spines and the betterpreserved dactyli as being conspecific.

Another surface detail observable on many specimens is a pattern of grooves running in smooth spirals (Figure 6C, D). This pattern is present in many of the isolated spines (specimens in Figure 5H, I, M-P, R-U). Such pattern has no equivalent in any other stomatopod known, fossil or extant, and is here considered because of the quality of preservation found at the study site.

With the length of the more complete dactyli as 


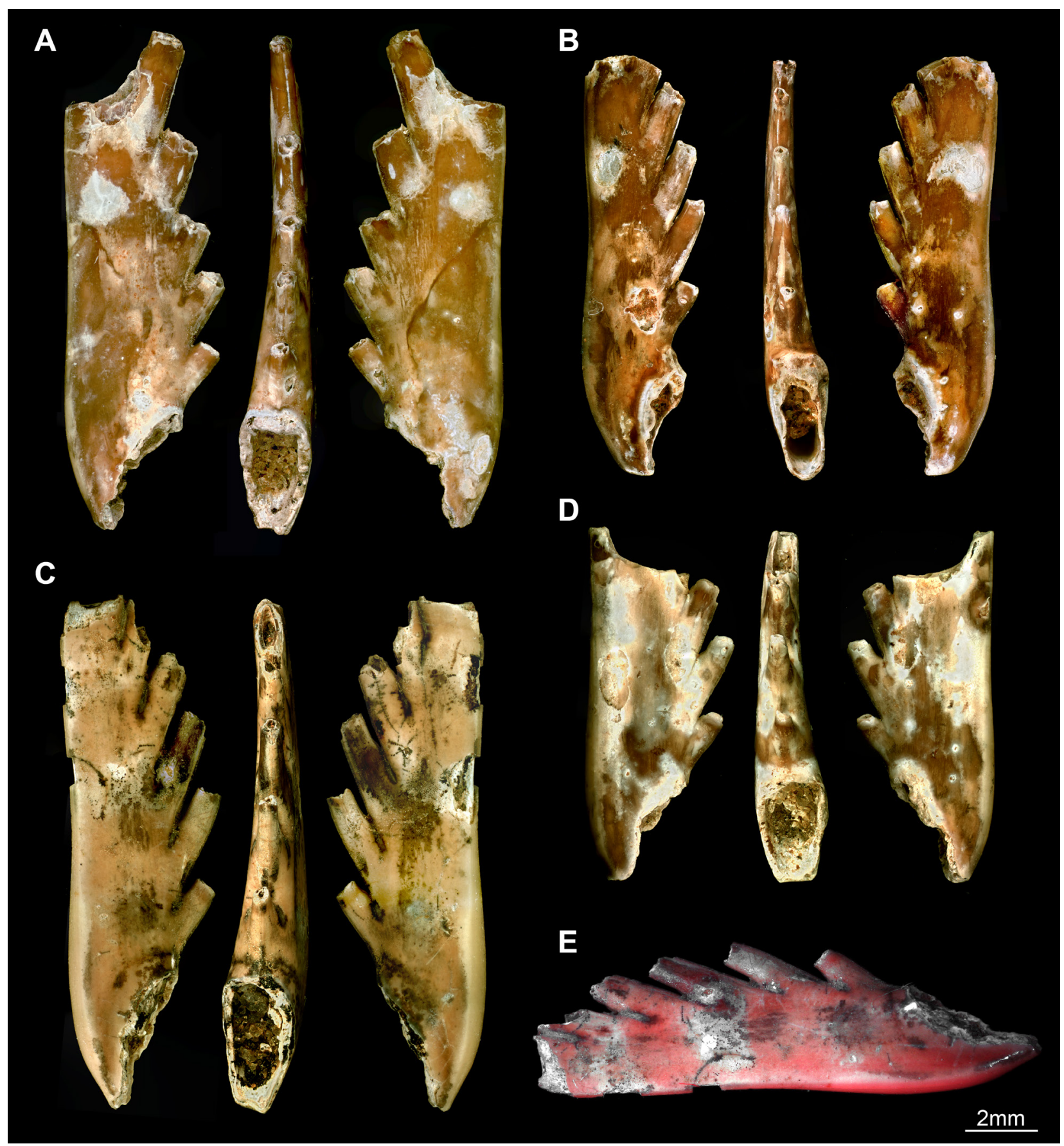

Figure 3. Most complete dactyli of the material examined. A-D) Specimens under polarized light, documented from both lateral sides and the functionally dorsal, adorned side (NCSM 11642 - 11645). E) Same specimen as in C under macro-fluorescence settings; pink areas indicate the presence of calcium phosphate.

reference, the estimated body size of the entire animal is calculated to $100-120 \mathrm{~mm}$ roughly, based upon our own unpublished comparative measurements of complete extant squillids (see discussion below for supposed systematic affinities). The dactyli represent a certain size range, yet not a very pronounced one. Due to the small variation, we assume that the size of the dactyli represents the final adult size, given that the estimated body size corresponds to that of the adult stage.

The composition material measured on the largest dactylus (Figure 3C, E) seems to be calcium phosphate, according to the X-ray fluorescence analysis. The presence of relatively strong autofluorescence detected with optical macro-fluorescence settings supports the presence of calcium phosphate (Figure 3E) (Haug C. et al., 2009a; Haug J.T. and Haug C., 2011; Haug J.T. et al., 2011). 


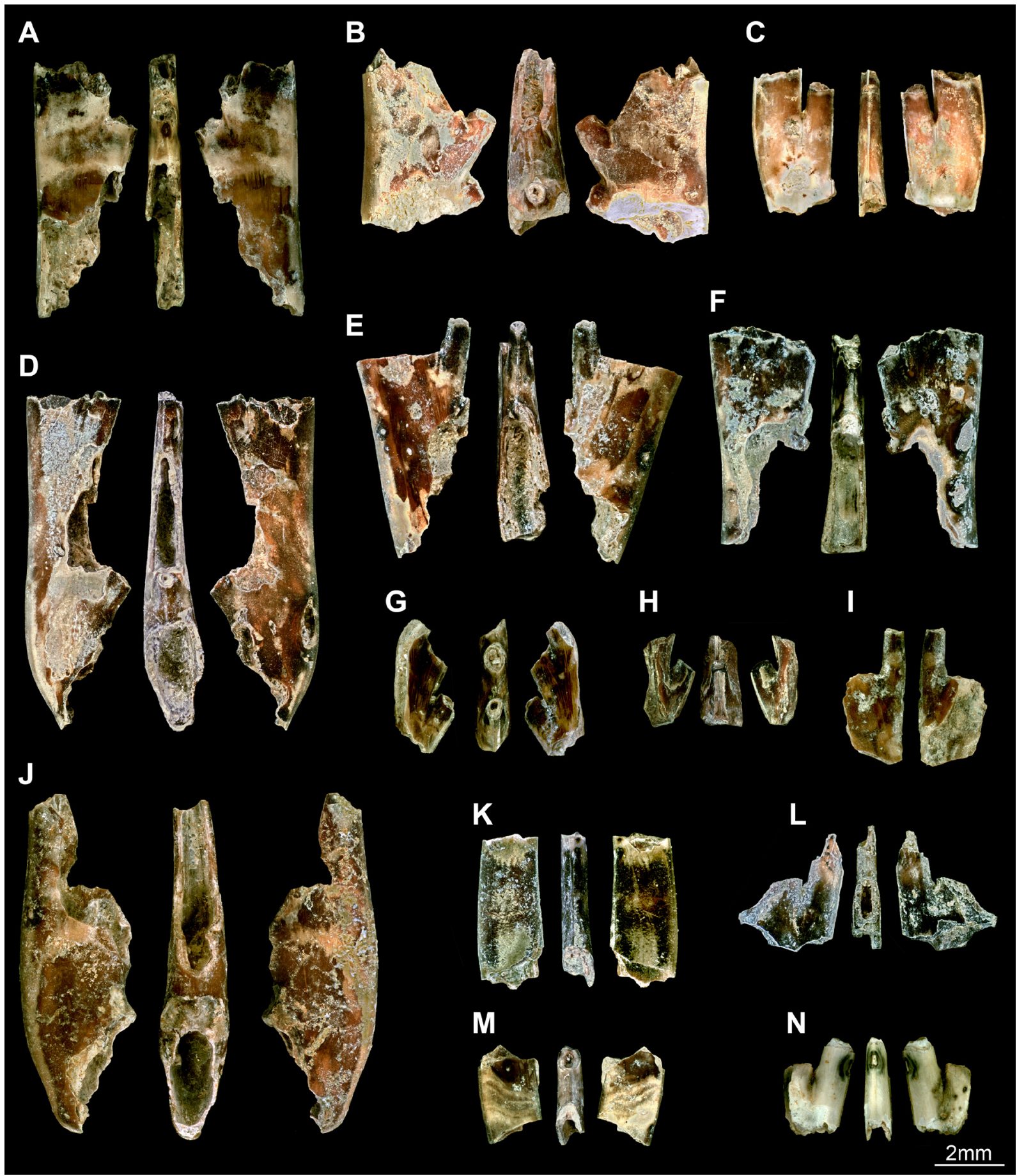

Figure 4. Central parts of dactyli. A-H, J-N) Specimens (NCSM 11646 - 11653, 11655-11659) documented from three sides as in Figure 3. I) Smaller specimen documented from two sides (NCSM 11654).

\section{Discussion}

\subsection{Systematic affinities}

Due to the fragmentary nature of the specimens, it is difficult to attribute the described dactyli to a particular species. We therefore compare the dactyli to those of stomatopods that live on the coast of North Carolina today.

Neogonodactylus bredini (Manning, 1969), N. oerstedii (Hansen, 1895), and N. torus (Manning, 1969) are boxertype stomatopods, thus they do not possess spine-bearing dactyli and cannot be the species represented in the heredescribed material (Schwartz and Porter, 1977; Morgan and Goy, 1987; Müller, 1994). Coronis scolopendra 


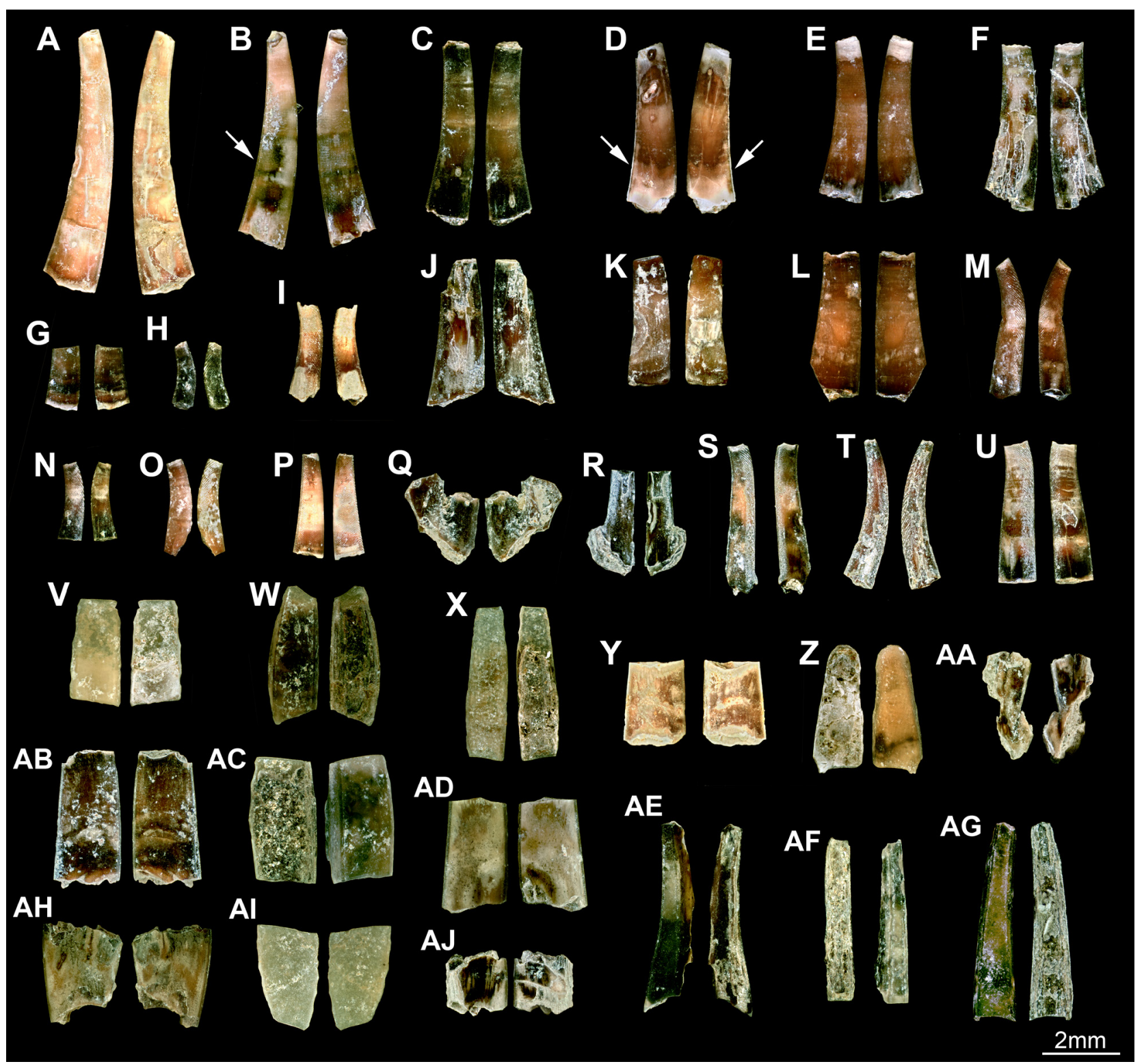

Figure 5. Isolated spines or cuticle parts of the main part of the dactyli (NCSM 11660 - 11675, $11677-11686$, NCSM 11689 - 11698). Note the narrow crest on the functional dorsal side in some of the specimens, e.g., in B and D (arrows) and the pattern of grooves running in smooth spirals in H, I, M-P, R-U; compare with Figure 6.

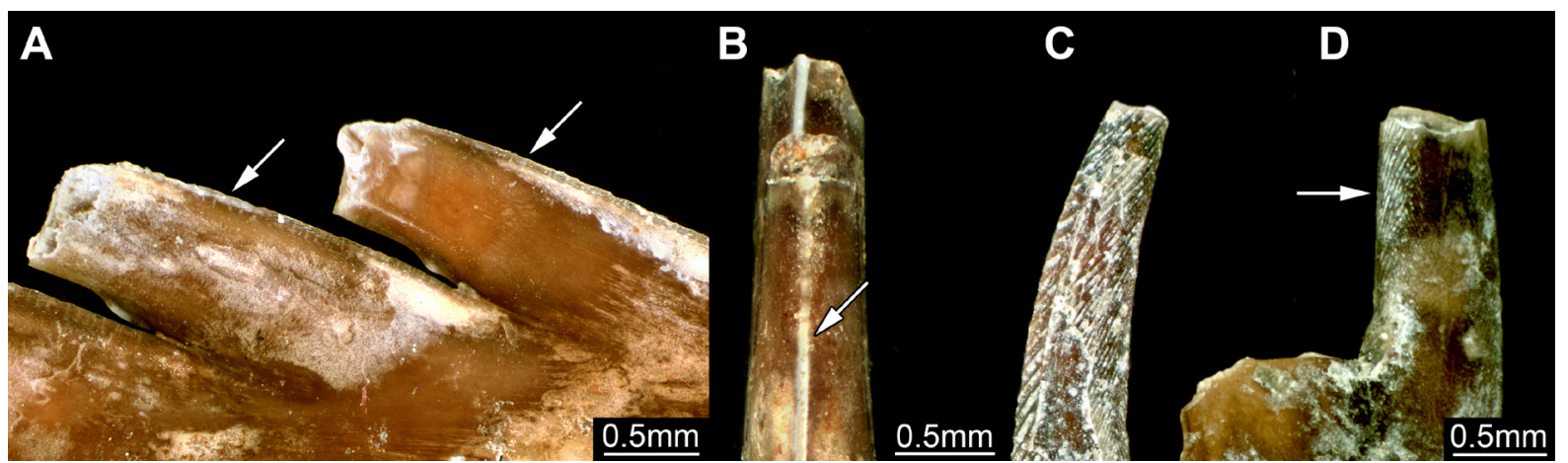

Figure 6. Details of the most complete dactyli. A-B). Narrow crest on the functionally dorsal side of the spines of the dactyli (arrows). A) Lateral view, same specimen as in Figure 3B (NCSM 11643). B) Functional dorsal view, same specimen as in Figure 4C (NCSM 11648). C-D) Pattern of grooves on the sides of the dactyli, probably of preservational origin. C) Pattern on complete specimen, same as in Figure 5T (NCSM 11680). D) Pattern near arrow, same specimen as in Figure 4I (NCSM 11654). 


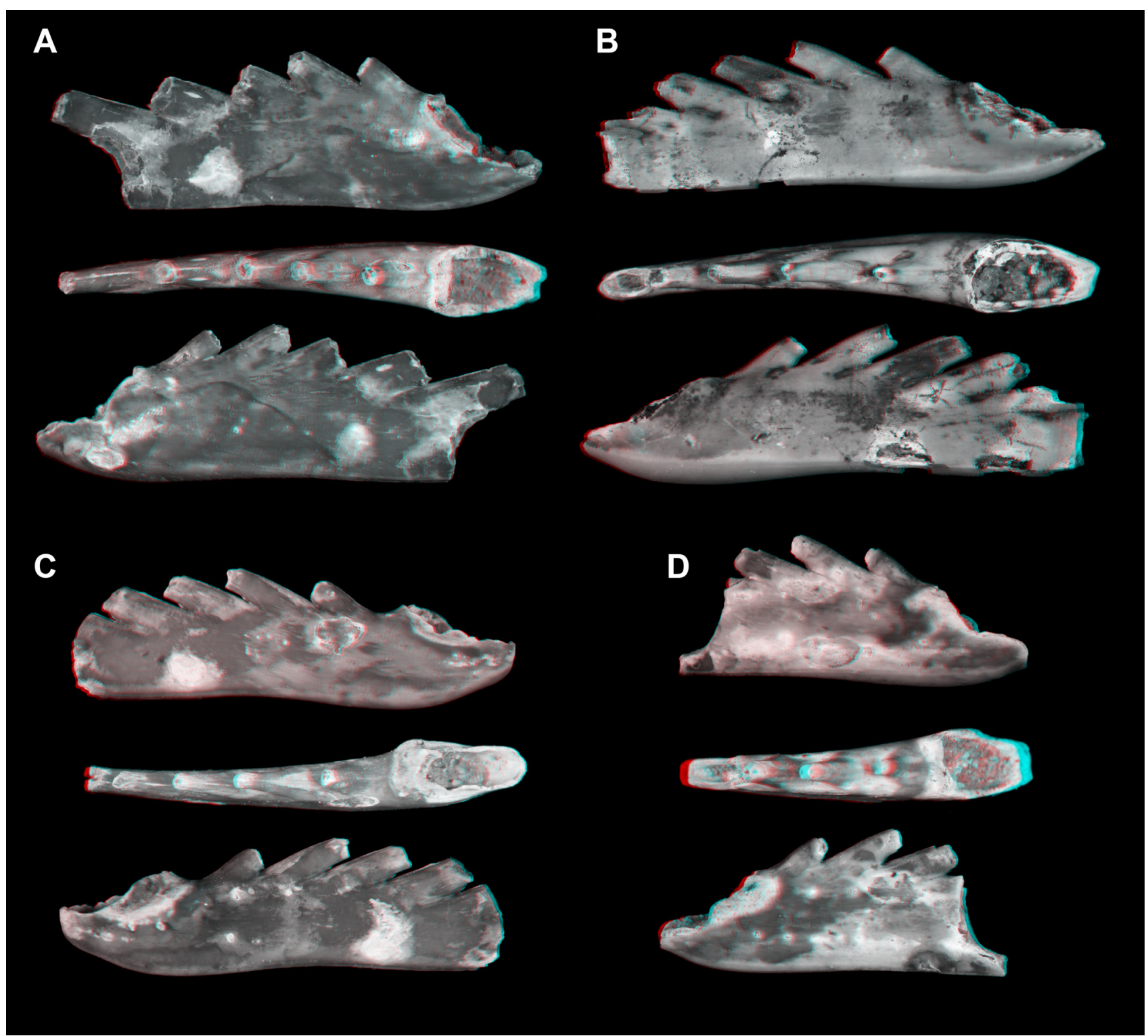

Figure 7. Stereo images of the most complete dactyli in three directions (like in Figure 3, same specimens); use red-cyan stereo glasses to view.

Latreille, 1828, Nannosquilla carolinensis (Manning, 1970), Platysquilloides enodis (Manning, 1962), and Squilla deceptrix (Manning, 1969) all do not exceed 70 $\mathrm{mm}$ in total length (Manning, 1970; Schram, 2010). The herein described dactyli are therefore too large to belong to representatives of these species.

Gibbesia neglecta (Gibbes, 1850) and Meiosquilla quadridens (Bigelow, 1893) both reach a size between $100-110 \mathrm{~mm}$, thus correspond in size to the estimated body size for the animals bearing the dactyli described herein. Yet, in these species the dactyli bear five and four spines respectively (Werding and Müller, 1990; Foster et al., 2004), whereas the dactyli described herein always possess six spines.

Squilla empusa (Say, 1818) reaches larger body size up to $185 \mathrm{~mm}$ (Schram, 2010). Additionally, S. empusa is known not only from extant forms, but the record reaches back into the Pleistocene of Maryland (Blake, 1953; trace fossils) and the late Pleistocene or early Holocene of Connecticut (Waage et al., 2001). The specimens described herein are relatively small, but still fit into the size range of $S$. empusa and closely resemble a fairly completely preserved dactylus in the material of Waage et al. (2001, their fig. 4C). An affinity based on the available characters cannot directly be shown. Yet, there is no character excluding an assumed affinity of the specimens described herein to $S$. empusa, which is also true for the size, and the Pleistocene-Holocene occurrences also bridge the time gap between the Pliocene material and the extant fauna. Until further evidence, the specimens should therefore be assigned to Squilla? empusa? (following the open nomenclature of Bengtson, 1988). 


\subsection{Scarcity of stomatopod fossil record}

The fossil record of Stomatopoda begins in the Carboniferous (Schram, 2007 and references therein). A single fragmentary specimen from the Silurian was interpreted by Wetzel (1973) as a possible part of a stomatopod telson. Attempts at locating the specimen have not yet been successful; however, based upon the image published it is doubtful that the specimen has a stomatopod affinity. In the Carboniferous numerous sites have yielded stomatopod fossils, e.g., the deposits of Mazon Creek and Bear Gulch, both North America, Hagen-Vorhalle in Germany, East Kilbride in Scotland, and Argenteau in Belgium. Fourteen species are currently recognized from this period, representing various evolutionary levels (e.g., Peach, 1908; van Straelen, 1922; Schöllmann, 2004; Schram, 2007, 2010; Haug J.T. et al., 2010).

There is no report of stomatopod fossils in the Permian and Triassic to date. Stomatopods have been found in the Lower Jurassic fossil in Osteno, Italy (Hof, 1998a) and they are currently under study by Italian and Australian researchers (Ahyong, pers. comm.). From the Upper Jurassic, four species have been described from lithographic limestones of southern Germany and a new species is yet to be named (summaries in Haug J.T. et al., 2008, 2010; Haug C. et al., 2009b). However, the taxonomic status of some of the species is currently under debate and it is most likely that some of these species will be synonymized (Haug J.T. et al., 2010).

In the Cretaceous, fossil stomatopods have been found in Lebanon (three species; Dames, 1886; Ahyong et al., 2007; Haug J.T. et al., 2010), USA (one species; Franţescu, 2012), Mexico (one possible, but not yet named species; Vega et al., 2007) and Colombia (one possible, but still to be named species; Feldmann et al., 1999). Furthermore, two verunipeltatan species are known from the Cretaceous of Colombia (Schram, 1968) and Nigeria (Förster, 1982). Five fossil specimens representing stomatopod tail ends from Israel and Jordan have been attributed to another ingroup species of Verunipelta, Ursquilla yehoachi (Remy and Avnimelech, 1955) (Hof, 1998b; Haug C. et al., 2013). Squilla cretacea (Schlüter, 1868) could not be successfully tracked yet, and its stratigraphic attribution has been considered as doubtful (Schram, 2010).

All Cenozoic occurrences appear to represent verunipeltatan species as well. No stomatopods have been found from the Palaeocene. From the Eocene to the Pleistocene, 30 species are known (five of them not yet formally described), with peaks in the Eocene and Miocene (although marine strata from the Oligocene are generally rare). Three of these species have survived until today (Schram, 2010). Deposits in northern Italy, mainly the famous lagerstätte Monte Bolca and the nearby Monte Postale, have yielded several stomatopod species (Secretan, 1975; Angeli and Beschin, 2006; Angeli and Garassino,
2008).

Given the relative incompleteness of the stomatopod fossil record, the finding of the here described isolated dactyli not only marks an additional occurrence, but it also gives the perspective that many stomatopod fossils could be represented by fragments, especially dactyli including by other parts, e.g., the telson (cf. Ursquilla yehoachi). Many fragments like the dactyli described will most likely not be identified to genus or even species level, yet they can still provide a source of data for answering different scientific questions.

\subsection{Impact on reconstructing the paleoenvironment}

Stomatopods represent important predators within their ecotope. Predators of this ecotype have been identified indirectly as trace fossils, back to Cambrian strata (Pratt, 1998). Yet, such an indirect finding often remains ambiguous. Finding isolated dactyli provides positive evidence that such predators were present in the paleoecosystem, i.e., a representative of the guild "ambush predator" was present. Additionally, it is difficult to estimate the population size from trace fossils such as hitting marks. Although it is also challenging to make such estimations based on fragmentary material, the amount of fragments found in North Carolina indicates that there was possibly a large population of mantis shrimps back in the Pliocene. Nevertheless, it must be considered that part of the material might stem from molts, which would distort the estimation of the population size.

As explained above, the number of stomatopod species is rather low in the fossil record, and individual fossils are relatively rare. Certain Carboniferous, Jurassic or Eocene species are known from numerous specimens (e.g., Secretan, 1975; Jenner et al., 1998; Angeli and Garassino, 2008; Haug J.T. et al., 2010), but other fossil stomatopods are only known from very few individuals (Hof, 1998b; Haug C. et al., 2009b, 2013) or in some cases from a single one (Ahyong et al., 2007; Schram, 2007).

Fragmentary specimens, which could have been overlooked, can add significantly more specimens and provide additional information for estimating population sizes. The potential for drawing scientific conclusions from isolated dactyli of decapod crustaceans has been proposed by Agnew (2008). Larger sample sizes could be used in a similar fashion with stomatopods. Despite of being important predators, stomatopods are also an attractive food source for larger predators (see Grimes, 1979 for an extant example). Regarding the Pliocene fish species found in the shell hash bed, evidenced by the presence of otoliths, the juveniles may well have been a food source for the larger spearer stomatopods at that time. In addition, the larger fishes could have used the juvenile stomatopods as a food source, thus contributing to the high degree of element fragmentation. As many paleo-food webs are not necessarily based on distinct species but more on ecotypes or guilds, 
the simple presence of these predators as indicated by such fragmentary specimens represents an important data point for such a kind of analysis.

The scarcity of the stomatopod fossil record has hampered a paleo-biogeographical approach, i.e., revealing possible connections between specific paleo-biotas. The presence of the dactyli described herein, that possibly belong to Squilla empusa, could imply that its modern distribution along the East coast of the United States of America was already established back in the Pliocene. Yet, the scarcity and fragmentary nature of both the fossils and the fossil record of mantis shrimps in general should lead to conclusions that are more cautious. The species affinity of the presented material to $S$. empusa is only likely, but not definitive. Even if this statement should be accepted, it could also be explained by a migration northwards from the Pliocene in North Carolina over the Pleistocene in Maryland on to the late Pleistocene or early Holocene in Connecticut, followed by a rather recent distribution along the entire coast. More material is needed before such conclusions can be drawn; yet, the presented material definitely yields potential for such approaches.

\subsection{Preservation}

Being preserved in calcium phosphate and representing a three-dimensional hollow replicate of the non-calcified cuticle, the here described specimens could be characterized as being preserved in an "Orsten"-sensu-lato-type preservation (Maas et al., 2006), which especially favors cuticle-bearing, unmineralized animals, and is restricted to a maximum size of $c a .2 \mathrm{~mm}$; however, the dacytli are significantly larger. Further insight is needed on whether other minerals besides calcium phosphate can be found in the specimens that facilitated the preservation in this size range. The usual question, regarding to calcium phosphatic preservation, is where the phosphate was originated. One possibility is that another decaying organism could have provided this material (Bate, 1972; Weitschat, 1983). In this case, perhaps the body of the stomatopod could have provided the phosphate to preserve just a tiny part of itself. More details on the paleoenvironment could provide further insight on this mode of preservation.

Other stomatopod fossils are also preserved in calcium phosphate, e.g., the specimens from the Upper Jurassic lithographic limestones of southern Germany (Solnhofen, Nusplingen). These fossils can also preserve their threedimensionality to a certain degree (Haug J.T. et al., 2010), but are usually affected by compaction (one notable exception of a decapod in Haug et al., 2009a, their figures 4.6-4.8).

The isolated dactyli therefore represent an exceptional example from a preservational point of view, being relatively large, but with high detail and three-dimensionally preserved in "Orsten"-sensu-lato-preservation. This special preservation may be partly coupled to the comparably young age of the dactyli. Other specimens in "Orsten"-sensu-latopreservation found in the Cenozoic, have been described from Australia, with preserved insects, i.e., terrestrial fauna (Duncan et al., 1998).

The preservation of the specimens described herein may not appear extraordinarily spectacular due to the fragmentary nature of the specimens. Yet, this is the first example in which the narrow crest on the functionally dorsal side of the spines is preserved on a fossil stomatopod. This crest acts mechanically as a knife-edge. The finding of this structure on the specimens presented herein emphasizes the exceptional preservation of these specimens.

\section{Conclusions and outlook}

The exceptionally preserved specimens of isolated stomatopod dactyli indicate that the fragmentary fossil record of stomatopods could be significantly amended with the search and description of additional fossil dactyli. Although such specimens do not allow exact taxonomic treatments, this kind of findings could be an important and underestimated data source for paleoenvironmental and paleobiogeographical studies.

\section{Acknowledgments}

We would like to thank Mr. Donald Clements for the study site specifics. Mr. Clements is a fellow fossil enthusiast that was instrumental in stressing the paleobiological importance of the Bladen County Annex site. Along with Mr. Clements, we would like to thank all amateur paleontologists that dedicated their time for supporting paleontological research. Joachim T. Haug at University of Greifswald photographed the specimens and processed the images, for which we are very thankful. $\mathrm{CH}$ expresses her thanks to her host during her time at Yale University, Derek E.G. Briggs. She is currently funded by a DAAD return fellowship. Many thanks also to her host Steffen Harzsch at the University of Greifswald. We are grateful to Yukiko Tonoike for performing the material analysis, and to Catherine Skinner for inspiring discussions on calcium phosphate occurrences in the environment, both at Yale University. We thank all people involved in providing free software that was used in the course of these studies, such as CombineZM, CombineZP, Microsoft ICE, and OpenOffice. Patricia G. Weaver (Collections Manager Geology/Paleontology, North Carolina Museum of Natural Sciences, Raleigh, NC) provided accession numbers for specimens here described. Reviews on the original document by Lothar Schöllmann, LWL-Museum für Naturkunde Münster, and Matúš Hyžný, University of Bratislava, are highly appreciated. 


\section{References}

Agnew, J.G., 2008, Dactyls reveal evolutionary patterns in decapod crustaceans: Baton Rouge, Los Angeles, Department of Geology and Geophysics, Louisiana State University and Agricultural and Mechanical College, 193p.

Ahyong, S.T., Garassino, A., Gironi, B., 2007, Archaeosculda phoenicia n. gen., n. sp. (Crustacea, Stomatopoda, Pseudosculdidae) from the Upper Cretaceous (Cenomanian) of Lebanon: Atti della Società italiana di Scienze naturali e del Museo civico di Storia naturale in Milano 2007, 148(I), 3-15.

Angeli, de A., Beschin, C., 2006, Stomatopodi terziari del Veneto (Italia settentrionale): Studi e Ricerche - Associazione Amici del Museo - Museo Civico "G. Zannato" Montecchio Maggiore (Vicenza), 13, 25-34.

Angeli, de A., Garassino, A., 2008, Pseudosquilla lessinea n. sp. (Crustacea, Stomatopoda, Pseudosquillidae) and Scyllarides bolcensis n. sp. (Crustacea, Decapoda, Scyllaridae) from the lower Eocene (Ypresian) of Monte Postale (Altissimo, Vicenza, NE Italy): Atti della Società italiana di Scienze naturali e del Museo civico di Storia naturale in Milano 2008, 149(II), 167-178.

Bate, R.H., 1972, Phosphatized ostracods with appendages from the Lower Cretaceous of Brazil: Palaeontology, 15, 379-393.

Bengtson, P., 1988, Open nomenclature: Palaeontology, 31(1), 223-227.

Bengtson, S., 2000, Teasing fossils out of shales with cameras and computers: Palaeontologia Electronica, 3(1), art.4, published 15 April 2000, available in $<\mathrm{http}: / /$ palaeo-electronica.org/2000_1/ fossils/issue1_00.htm>, consulted 30 June 2013.

Bigelow, R.P., 1893, The Stomatopoda of Bimini: Johns Hopkins University Circular, 12(106), 102-103.

Blake, S.F., 1953, The Pleistocene fauna of Wailes Bluff and Langleys Bluff, Maryland: Smithsonian Miscellaneous Collection, 121(12), 1-32.

Bonaparte, C.L., 1831, Saggio di una distribuzione metodica degli animali vertebrati: Antonio Boulzaler, Roma, $78 \mathrm{p}$.

Boxshall, G.A., Jaume, D., 2009, Exopodites, epipodites and gills in crustaceans: Arthropod Systematics and Phylogeny, 67, 229-254.

Campbell, M.R., Campbell, L.D., 1995, Preliminary Biostratigraphy and Molluscan Fauna of the Goose Creek Limestone of Eastern South Carolina: Tulane Studies in Geology and Paleontology, 27, 53-100.

Carter, J.G., Gallagher, P.E., Vallone, R.E., Rossbach, T.J., Gensel, P.G., Wheeler, W.H., Whitman, D., 1988, Fossil collecting in North Carolina: North Carolina Geological Survey Bulletin, 89, 89 p.

Chiou, T-H., Kleinlogel, S., Cronin, T., Caldwell, R., Loeffler, B., Siddiqi, A., Goldizen, A., Marshall, J., 2008, Circular polarization vision in a stomatopod crustacean: Current Biology, 18, 429-434.

Conrad, T.A., 1834, Descriptions of new Tertiary fossils from the Southern States: Journal of the Academy of Natural Sciences of Philadelphia, $7(1), 130-157$.

Dames, W., 1886, Ueber einige Crustaceen aus den Kreideablagerungen des Libanon: Zeitschrift der Deutschen Geologischen Gesellschaft, 38(3), 551-576.

Duncan, I.J., Briggs, D.E.G., Archer, M., 1998, Three-dimensionally mineralized insects and millipedes from the Tertiary of Riversleigh, Queensland, Australia: Palaeontology, 41, 835-851.

Feldmann, R.M., Villamil, T., Kauffman, E.G., 1999, Decapod and stomatopod crustaceans from mass mortality lagerstatten: Turonian (Cretaceous) of Colombia: Journal of Paleontology, 73, 91-101.

Fitch, J.E., Lavenberg, R.J., 1983, Teleost Fish Otoliths from Lee Creek Mine, Aurora, North Carolina, in Ray, C.E. (ed.) Geology and Paleontology of the Lee Creek Mine, North Carolina, I: Whashington, D.C., Smithsonian Contributions to Paleobiology, $53,509-529$.

Förster, R., 1982, Heuschreckenkrebse (Crustacea: Stomatopoda) aus dem Alttertiär von Helmstedt und Handorf (Niedersachsen) und der Oberkreide von Nigeria: Neues Jahrbuch fuer Geologie und Paläontologie Monatschafte, 1982, 321-335.

Foster, J.M., Thoma, B.P., Heard, R.W., 2004, Stomatopoda (Crustacea:
Hoplocarida) from the shallow, inshore waters of the northern Gulf of Mexico (Apalachicola River, Florida to Port Arkansas, Texas): Gulf and Caribbean Research, 16, 49-58.

Franţescu, O.D., 2012, Nodosculda fisherorum, new genus and new species of mantis shrimp (Stomatopoda: Sculdidae) from the Cretaceous (Late Albian) of Texas, USA: Journal of Crustacean Biology, 32, 774-779.

Gibbes, L.R., 1850, On the carcinological collections of the cabinets of natural history in the United States, with an enumeration of the species contained therein, and descriptions of new species: Proceedings of the American Association for Advancement of Science, 3rd meeting, 167-201.

Gill, T., 1861, Revision of the genera of North American Sciaeninae: Proceedings of the Academy of Natural Sciences of Philadelphia, $13,79-89$.

Gill, T., 1863, Catalogue of the North American sciaenoid fishes: Proceedings of the Academy of Natural Sciences of Philadelphia, $15,28-32$.

Gould, A.A., 1851, Dr. Samuel Cabot in the Chair: Proceedings of the Boston Society of Natural History, 4, 87-95.

Grimes, C.B., 1979, Diet and feeding ecology of the vermillion snapper, Rhomboplites aurorubens (Cuvier) from North Carolina and South Carolina waters: Bulletin of Marine Science, 29, 53-61.

Hansen, H.J., 1895, Isopoden, Cumaceen und Stomatopoden der PlanktonExpedition: Ergebnisse der in dem Atlantischen Ocean von Mitte Juli bis Anfang November 1889 ausgeführten Plankton-Expedition der Humboldt-Stiftung 2, 1-105.

Haug, C., Haug, J.T., Waloszek, D., Maas, A., Frattigiani, R., Liebau, S., 2009a, New methods to document fossils from lithographic limestones of southern Germany and Lebanon: Palaeontologia Electronica, 12(3), art.6T, published December 2009, available in $<$ http://palaeo-electronica.org/2009_3/193/index.html $>$, consulted 30 June 2013

Haug, C., Haug, J.T., Waloszek, D., 2009b, Morphology and ontogeny of the Upper Jurassic mantis shrimp Spinosculda ehrlichi n. gen. n. sp. from southern Germany: Palaeodiversity, 2, 111-118.

Haug, C., Kutschera, V., Ahyong, S.T., Vega, F.J., Maas, A., Waloszek, D., Haug, J.T., 2013, Re-description of the Mesozoic mantis shrimp Ursquilla yehoachi based on new material and the virtual peel technique: Palaeontologia Electronica, 16, 2, art. 5T.

Haug, C., Mayer, G., Kutschera, V., Waloszek, D., Maas, A., Haug, J.T., 2011, Imaging and documenting gammarideans: International Journal of Zoology, art. 380829.

Haug, J.T., Haug, C., 2011, Fossilien unter langwelligem Licht: GrünOrange-Fluoreszenz an makroskopischen Objekten: Archaeopteryx, $29,20-23$

Haug, J.T., Haug, C., Ehrlich, M., 2008, First fossil stomatopod larva (Arthropoda: Crustacea) and a new way of documenting Solnhofen fossils (Upper Jurassic, Southern Germany): Palaeodiversity, 1, 103-109.

Haug, J.T., Haug, C., Maas, A., Kutschera, V., Waloszek, D., 2010, Evolution of mantis shrimps (Stomatopoda, Malacostraca) in the light of new Mesozoic fossils: BMC Evolutionary Biology, 10, 290, $17 \mathrm{p}$.

Haug, J.T., Haug, C., Kutschera, V., Mayer, G., Maas, A., Liebau, S., Castellani, C., Wolfram, U., Clarkson, E.N.K., Waloszek, D., 2011, Autofluorescence imaging, an excellent tool for comparative morphology: Journal of Microscopy, 244, 259-272.

Hof, C.H.J., 1998a, Fossil stomatopods (Crustacea: Malacostraca) and their phylogenetic impact: Journal of Natural History, 32, 1567-1576.

Hof, C.H.J., 1998b, Late Cretaceous stomatopods (Crustacea: Malacostraca) from Israel and Jordan: Contributions to Zoology, 67(4), 257-266.

Jenner, R.A., Hof, C.H.J.,Schram, F.R., 1998, Palaeo- and archaeostomatopods (Hoplocarida, Crustacea) from the Bear Gulch Limestone, Mississipian (Namurian), of Central Montana: Contributions to Zoology, 67(3), 155-185.

Kerp, H., Bomfleur, B., 2011, Photography of plant fossils-New techniques, old tricks: Review of Palaeobotany and Palynology, 166, 117-151. 
Kleinlogel, S., Marshall, N.J., 2006, Electrophysiological evidence for linear polarization sensitivity in the compound eyes of the stomatopod crustacean Gonodactylus chiragra: Journal of Experimental Biology, 209, 4262-4272.

Lamarck, J.-B., 1799, Tome second, in Encyclopédie méthodique: Histoire naturelle des vers, par Bruguière, J.G., Lamarck, J. B. de, continuée par G. P. Deshayes, Paris, Panckoucke, 1789-1832.

Latreille, P.A., 1802, Histoire naturelle, générale et particulière, des Crustacés et des Insectes 3. F. Dufart, Paris, 653p

Latreille, P.A., 1816, Les crustacés, les arachnides et les insectes, in Cuvier, G. (ed.), Le règne animal distribué d'après son organisation, pour servir de base à l'histoire naturelle des animaux et d'introduction à l'anatomie comparée, 3, Paris, Déterville, 432p.

Latreille, P.A., 1828, Squille, Squilla, Encyclopédie méthodique histoire naturelle, insectes, 10, 467-475.

Maas, A., Braun, A., Dong, Xi-P., Donoghue, P.C.J., Müller, K.J., Olempska, E., Repetski, J.E., Siveter, D.J., Stein, M., Waloszek, D., 2006, The 'Orsten' - more than a Cambrian Konservat-Lagerstatte yielding exceptional preservation: Palaeoworld, 15, 266-282.

Maas, A., Haug, C., Haug, J.T., Olesen, J., Zhang, X., Waloszek, D., 2009, Early crustacean evolution and the appearance of epipodites and gills: Arthropod Systematics and Phylogeny, 67, 255-273.

Manning, R.B., 1962, Seven new species of stomatopod crustaceans from the northwestern Atlantic: Proceedings of the Biological Society of Washington, 75, 215-222.

Manning, R.B., 1969, Stomatopod Crustacea from the Western Atlantic: Studies in Tropical Oceanography 8, Institute of Marine Science, University of Miami, $380 \mathrm{p}$.

Manning, R.B., 1970, Nine new American stomatopod crustaceans: Proceedings of the Biological Society of Washington, 83, 8, 99-114.

Morgan, S.G., Goy, J.W., 1987, Reproduction and larval development of the mantis shrimp Gonodactylus bredini (Crustacea: Stomatopoda) maintained in the laboratory: Journal of Crustacean Biology, 7, 4, 595-618

Müller, H.-G., 1994, World catalogue and bibliography of the Recent Stomatopoda: Berlin, Wissenschaftlicher Verlag, 228 p.

Patek, S.N., Korff, W.L., Caldwell, R.L., 2004, Deadly strike mechanism of a mantis shrimp: Nature, 428, 819-820.

Peach, B.N., 1908, A monograph on the higher Crustacea on the Carboniferous rocks of Scotland: Geological Survey of Great Britain, Memoirs, 1908, $82 \mathrm{p}$.

Pratt, B.R., 1998, Probable predation on Upper Cambrian trilobites and its relevance for the extinction of soft-bodied Burgess Shale-type animals: Lethaia, 31, 73-88.

Rafinesque, C.S., 1815, Analyse de la nature, ou tableau de l'univers et des corps organisés. Palerme, 1-224.

Remy, J.-M., Avnimelech, M., 1955, Eryon yehoachi nov. sp. et Cenomanocarcinus cf. vanstraeleni Stenzel Crustacés décapodes du Crétacé supérieur de l'état de l'Israël: Bulletin de la Société Géologique de France, 5, 311-314.

Risso, A., 1826, Histoire naturelle des principales productions de l'Europe Méridionale et particulièrement de celles des environs de Nice et des Alpes Maritimes,4(IV), 439 p., 12 pl. Paris, Levrault.
Say, T., 1818, An account of the Crustacea of the United States: Journal of the Academy of Natural Sciences of Philadelphia, 1, 235-253.

Schaarschmidt, F., 1973, Pflanzenfossilien in ungewöhnlichem Licht: Natur und Museum, 103, 247-253.

Schlüter, C., 1868, Neue Fische und Krebse aus der Kreide von Westphalen: Palaeontographica 15, 303-304.

Schöllmann, L., 2004, Archaeostomatopodea (Malacostraca, Hoplocarida) aus dem Namur B (höheres Marsdenium, Karbon) von HagenVorhalle (NRW, Deutschland) und eine Neudefinition einiger Arten der Familie Tyrannophontidae): Geologie und Paläontologie in Westfalen, 62, 111-141.

Schram, F.R., 1968, Paleosquilla gen. nov.-a stomatopod (Crustacea) from the Cretaceous of Colombia: Journal of Paleontology, 42, 5, 1297-1301.

Schram, F.R., 1986, Crustacea. Oxford University Press, New York, Oxford, $606 \mathrm{p}$.

Schram, F.R., 2007, Paleozoic proto-mantis shrimp revisited: Journal of Paleontology, 81, 895-916.

Schram, F.R., 2010, Catalog of the Fossil and Recent Stomatopoda. Bay Ridge Press, Langley, Washington, USA, 294 p.

Schwartz, F.J., Porter, H.J., 1977, Fishes, macroinvertebrates, and their ecological interrelationships with a calico scallop bed off North Carolina: Fishery Bulletin, 75, 427-446.

Secretan, S., 1975. Les crustacés du Monte Bolca: Studi e Ricerche sui giacimenti terziari di Bolca. Miscellanea paleontologica. Museo Civico di Storia Naturale di Verona, 2, 315-388.

Straelen, V. van, 1922, Quelques eumalacostracés nouveaux inférieur d'Argenteau prés Liège : Annales de la Société geologique de Belgique, 45, M35-M40.

Vega, F.J., Nyborg, T., Briceño, A.R., Patarroyo, P., Luque, J., PorrasMúzquiz, H., Stinnesbeck, W., 2007, Upper Cretaceous Crustacea from Mexico and Colombia: Similar faunas and environments during Turonian times: Revista Mexicana de Ciencias Geológicas, 24(3), 403-422.

Waage, K.M., MacClintock, C., Hickey, L.J., 2001, Post-glacial fossils from Long Island Sound off West Haven, Connecticut: Postilla, 225, 1-26.

Ward, L.W., Gilinsky, N.L., 1993, Molluscan Assemblages of the Chowan River Formation, Part A: Virginia Museum Natural History Memoir, $3,34 \mathrm{p}$.

Weitschat, W., 1983, Ostracoden (O. Myodocopida) mit WeichkörperErhaltung aus der Unter-Trias von Spitzbergen: Paläontologische Zeitschrift, 57, 309-323.

Werding, B., Müller, H.-G., 1990, Estomatópodos (Crustacea: Stomatopoda) de la costa norte de Colombia: Caribbean Journal of Science, 26, 104-121.

Wetzel, W., 1973, Zwei altpaläozoische Geschiebe mit neuartigen problematischen Fossilien: Schriften des Naturwissenschaftlichen Vereins für Schleswig-Holstein, 43, 44-45.

Manuscript received: September 2, 2012.

Corrected manuscript received: October 21, 2012.

Manuscript accepted: October 22, 2012. 